\title{
Effectiveness Trichoderma asperellum on the Growth Cocoa Seeds under the Old Cocoa Trees
}

\author{
Marliana S. Palad ${ }^{1}$, Ambo Ala ${ }^{2}$, Nasaruddin ${ }^{2} \&$ Nadira Sennang ${ }^{2}$ \\ ${ }^{1}$ Program of Agricultural Sciences, Graduate Hasanuddin University, Indonesia \\ ${ }^{2}$ Agroteknologi Studies Program, Faculty of Agriculture, Hasanuddin University, Indonesia \\ Correspondence: Marliana S.Palad, Program of Agricultural Sciences, Graduate Hasanuddin University, \\ Makassar 90245, Indonesia. Tel: 62-8529-980-1395. Email: lallypalad@yahoo.co.id
}

Received: June11, 2016

Accepted: July3, 2016

Online Published: August 17, 2016

doi:10.5539/mas.v10n11p176

URL: http://dx.doi.org/10.5539/mas.v10n11p176

\begin{abstract}
This study aimed to determine the effect of Trichoderma asperellum on the growth of cocoa seedlings under cocoa stands around 20 years old, so that cocoa seedlings to be used as rootstock on approach grafting for the rehabilitation of the roots of cocoa plants are old, growing well. Research compiled by randomized block design with frequency variation application $T$. asperellum that, once, twice and three times application respectively of 4 gr. $\mathrm{L}^{-1}$ each plant. The results of the research, granting T. asperellum on cocoa seedlings planted under old cocoa trees and is still productive, able to help overcome competition in the utilization of nutrients and water as well as other growth inhibiting factors, and the influential on the vegetative growth of cocoa seedlings. Frequency of the best is three times the application that provides the most effective results for growing cocoa seeds, the seed growing percentage of $100 \%$ and an average plant height of $144.45 \mathrm{~cm}$; number of leaves 37 strands; stem diameter $12.22 \mathrm{~mm}$; and total leaf area $1388.30 \mathrm{~cm} 2$.
\end{abstract}

Keywords: frequency of application, MCC-01, old cocoa, Trichoderma asperellum

\section{Introduction}

Cocoa (Theobroma cacao L.) is the essential raw commodity for the world's chocolate industry, which was worth $\$ 150$ bn in 2014. By 2016, the global chocolate market will be worth $\$ 98.3$ billion. Indonesian is the world's third leading producer of cocoa beans after Ghana and Ivory Coast, growing 740.500 tonnes in 2012, according to the FAO (Worldatlas, 2015).

West Sulawesi contributed 20\% of the national cocoa production, and is the largest cocoa producer in Indonesia, with the area planted in 2014 is 172,000 hectares with a production of 110-115 thousand tons per year (Anonymous, 2014). These data indicate that cocoa is the backbone of the economy in West Sulawesi, but ironically in West Sulawesi cocoa productivity continues to decline. Several factors are significant on the level of productivity of cocoa, besides extensive cocoa plantations, varieties, pests and diseases, climate anomalies, the plant canopy is damaged, as well as age older plants cause less productive plants (Anaeani \& Frimpong, 2013). In addition, the dominant limiting factors increasing of cocoa productivity is soil fertility including low organic matter content, low exchange able minerals nutrients such as K and low soil CEC (Ololade, 2010).

Side-grafting is the introduction of cultivation technology that quickly spread among farmers, which initially gives hope bright enough in order to improve the productivity of cocoa. However, after the results are satisfactory side-grafting produce multiple harvests, further crop losses in production and productivity. This is likely caused by an imbalance of the capability of the plant canopy to produce, with the condition that the old plant root system in supplying the needs of nutrients and water from the roots.

The work can be done to fix the root system of the tree cacao side grafting is a technique of approach-grafting, by utilizing the cocoa seeds that have been aged for at least 6 months, so that plant roots can be rehabilitated and is expected cocoa productivity can be improved. The success of this effort is especially if the cocoa seedlings that will be continued to grow well. Cocoa seedlings were planted under old cocoa stand side grafting productive results, will have competition in the use of water and nutrients to the vegetative growth.

One functional microorganism that is widely known as a biological fertilizer the soil is Trichoderma sp.These 
microorganisms are fungi occupants of the land that can be isolated from plant roots field, including cocoa. Species Trichoderma as well as decomposing organisms, can also function as biological agents and plant growth stimulator (Okoth etal.,2011; Anad \& Reddy, 2009; Saba etal.,2012). For example Trichoderma harzianumgive the same response to auxin in improving the cocoa plant roots extension (Nurahmi etal.,2012). Trichoderma also produce phytohormones ET and IAA, which plays a role in the sustainability of the growth of plants and plant resistance to disease control and adverse environmental conditions (Hermosa etal., 2012).

Based on this, Trichoderma sp. is expected to help overcome the competition to get water and nutrients and factors inhibiting the growth of other, so the cocoa seedlings to be used as rootstock on approachgraftingfor the rehabilitation of the roots of cocoa plants are old, can grow well.

The results of research on the role of Trichoderma sp. of the cocoa plant is a lot, especially as disease control in cocoa, such as leaf blight, pod disease and cancer stem caused by Phytophthorapalmivora (Asti et al., 2013; Adebola \& Amadi, 2012). Bae et al. (2009) reported that Trichoderma sp. resulted in cocoa seedlings are more tolerant to drought. Technology of Trichoderma $s p$. is growing rapidly, but the information about the role of Trichoderma $s p$. in addressing competition cocoa seedlings were planted in the area around the plant roots productive yet available. This study aimed to determine the effect of Trichoderma $s p$. to the growth of cocoa seedlings under stands of old cocoa productive.

\section{Materials and Methods}

The experiment was conduted infarm field of Bunde village, Sampaga district, Mamuju regency, West Sulawesi. Six months old cocoa seedlings planted under the cocoa tree stand of around 20 years old, with a spacing of $3 \times 3$ m. Planting hole was made with size of $40 \times 40 \times 30 \mathrm{~cm} 3$ hole, and in distance of $20 \mathrm{~cm}$ from old cocoa tree.

The materials used are the seeds of Theobroma cacao variety Masamba Cocoa Clone (MCC) 01, Trichoderma asperellum isolates ART-4 were obtained from Laboratory of Microbiology Faculty of Agriculture University of Hasanuddin, manure, NPK, meter, shove, and so on. The experiments used designed randomized block design (RBD) with frequency treatment applications of T. asperellum. The provision of $T$. asperellum: one time, two times, three times application of T. asperellum respectively of 4 gr. $\mathrm{L}^{-1}$ each plant and wihout application. The first application was given at the time of planting and subsequent intermittent applications a week later. Each treatment was repeated 3 times, so the total plants totaling 36 plants observed.

To assess the effect of treatment, it was carried out observations of parameters including average plant height (cm) measured from a height of $2 \mathrm{~cm}$ from ground level to the growing point of the top, the average number of leaves (leaf) formed, average trunk diameter $(\mathrm{mm}) 5 \mathrm{~cm}$ from ground level, and the average total leaf area $\left(\mathrm{cm}^{2}\right)$ was measured using graph paper (Nasaruddin, 2011) with the formula:

$$
\mathrm{LD}=\mathrm{n} \times \mathrm{k}(1)
$$

LD is the leaf area $\left(\mathrm{cm}^{2}\right), \mathrm{n}$ is the number of boxes, and $\mathrm{kk}$ is the area of each box $\left(1 \mathrm{~cm}^{2}\right)$

To determine the effect of treatment on the parameters observed, an analysis of variance and if there is a treatment effect were significantly different followed by Least Significant difference test (LSD) with significance level of $5 \%$.

\section{Results and Discussion}

Observations were done to determine the physical and chemical properties of the soil. The results of the analysis of soil chemical properties in the study area is a total- $\mathrm{N}, \mathrm{C} / \mathrm{N}$ ratio, organic $\mathrm{C}, \mathrm{K}$ and $\mathrm{Na}$ is low, $\mathrm{pH}, \mathrm{Ca}$ and $\mathrm{P}_{2} \mathrm{O}_{5}$, is classified, and $\mathrm{Mg}$ and $\mathrm{CEC}$ is high and the type of clay clayey (Tab. 1).

Table 1. Chemical and physical properties of soil in the experiment

\begin{tabular}{ll}
\hline \multicolumn{2}{l}{ soil chemical properties } \\
\hline $\mathrm{pH} \mathrm{H} \mathrm{H}_{2} \mathrm{O}$ & 6,2 \\
$\mathrm{~N}$ total $(\%)$ & 0,11 \\
organic $\mathrm{C}(\%)$ & 1,08 \\
$\mathrm{C} / \mathrm{N} \mathrm{ratio}$ & 10 \\
$\mathrm{P}_{2} \mathrm{O}_{5}(\mathrm{ppm})$ & 10,9 \\
$\mathrm{Ca}(\mathrm{cmol} / \mathrm{kg})$ & 6,84 \\
$\mathrm{Mg}(\mathrm{cmol} / \mathrm{kg})$ & 3,52 \\
$\mathrm{Na}(\mathrm{cmol} / \mathrm{kg})$ & 0,19 \\
\hline
\end{tabular}




\begin{tabular}{ll}
\hline CEC (cmol / kg) & 25,66 \\
soil texture & \\
Sand (\%) & 32 \\
dust (\%) & 30 \\
Clay (\%) & 38 \\
\hline
\end{tabular}

Note.Source: Lab. Chemistry and Soil Fertility, Soil Department Agriculture Fakulty, Hasanuddin University

The provision of T. asperellum was very influential on the vegetative growth of cocoa seedlings planted under old cocoa stand still in production (Tab. 2).

Table 2. Effect of Frequency Applications T. asperellum of the vegetative growth of cocoa seedlings age of 12 weeks after treatment applications in the field

\begin{tabular}{cccccc}
\hline Treatment & $\begin{array}{c}\text { Height } \\
\text { Plant } \\
(\mathrm{cm})\end{array}$ & $\begin{array}{c}\text { Number of } \\
\text { leaves } \\
\text { (leaf) }\end{array}$ & $\begin{array}{c}\text { Stem } \\
\text { Diameter } \\
(\mathrm{mm})\end{array}$ & $\begin{array}{c}\text { Total leaf } \\
\text { area } \\
\left(\mathrm{cm}^{2}\right)\end{array}$ & $\begin{array}{c}\text { Percentage } \\
\text { Growth } \\
(\%)\end{array}$ \\
\hline without application & $109.33 \mathrm{a}$ & $24.56 \mathrm{a}$ & 8,55 & $999,72 \mathrm{a}$ & $52 \mathrm{a}$ \\
one-time application & $134 \mathrm{~b}$ & $32.89 \mathrm{~b}$ & 10,89 & $1357,22 \mathrm{~b}$ & $83 \mathrm{~b}$ \\
two-times application & $134.44 \mathrm{~b}$ & $32.78 \mathrm{~b}$ & 10,44 & $1302,84 \mathrm{~b}$ & $94 \mathrm{bc}$ \\
three-times application & $144.45 \mathrm{c}$ & $37 \mathrm{c}$ & 12,22 & $1388,30 \mathrm{~b}$ & $100 \mathrm{c}$ \\
LSD 0.05 & 8.90 & 2.05 & th & 130.79 & 13.21 \\
CV (\%) & 5.91 & 5.59 & 12.35 & 8.98 & 15.27 \\
\hline
\end{tabular}

Note.Description:Figures followed by the same letters in the same column are not significantly different according to LSD test level of 5\%

Growth of cocoa seedlings the highest and have the most was the number of leaves on the seedlings by $T$. asperellum for three times application and significantly different from other treatments. In total leaf area, giving Trichoderma asperellum once, two times and three times did not differ very significantly different result but with no provision of this fungus. Giving T. asperellum did not significantly affect seedling stem diameter, but the percentage of seedlings grown greatly affected by the fungus is mainly on the treatment two to three times as many applications. This indicates that the application of T. asperellum can increase vegetative growth is better than without the provision of T. asperellum.

The foregoing is highly correlated with the intensity of growth (elongation rate) shoots high. As we know that the growth of the plant involves a number of processes, such as multiplication and differentiation of cells (Basri, 2004). Cell multiplication caused more cell mass (as in the elongation and enlargement of the trunk diameter) while the cell differentiation leads to formation of tissues or organs (such as increasing the number of leaves). Thus, it is clear that with the increase of the length and diameter of the rod will be accompanied by the establishment organs, such as the size (length and width) as well as the number of leaves on shoots of cocoa. As we know that there are a number of factors that influence the growth of planting material, including external factors (environment such as climate, soil and applied technology) and internal factors (genetic including the quality and size of the mass meristem cells contained in a planting material) (Fosket, 1999; Hopkins, 1999).

The regression analysis in Figure 1 show that aplication of $T$. asperellum positively correlated linearly with the vegetative growth of cocoa seedlings age of 12 weeks after treatment. The more the frequency of application of $T$. asperellum increasingly better the vegetative growth of cocoa seedlings. 

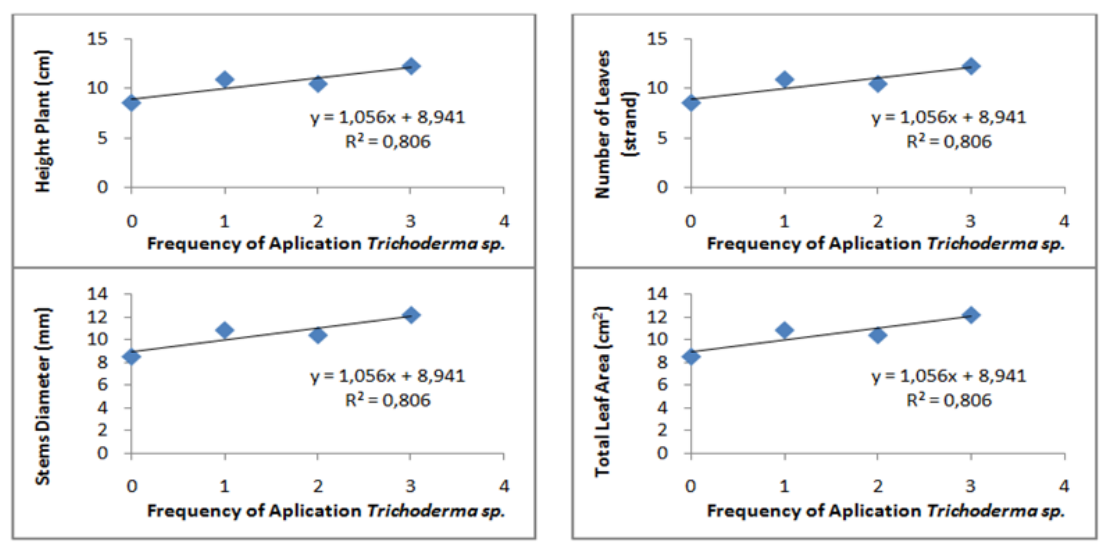

Figure 1. Graph of the regression equation vegetative growth of cocoa seedlings age of 12 weeks after treatment applications in the field

Based on the figure above shows that each increase of one unit of frequency applications T. asperellum with a dose of $4 \mathrm{gr.L} \mathrm{L}^{-1}$ will increase by $7.07 \mathrm{~cm}$ plant height, leaf number 3.72 strands, stem diameter of $1.06 \mathrm{~mm}$ and leaf area of $111.1 \mathrm{~cm}^{2}$. Giving $T$. asperellum able to increase vegetative growth of cocoa seedlings, because fixing rhizosphere plant roots and helps decompose soil organic matter into nutrients that plants need for growth (Adedeji, 2008). The existence of T. asperellum on the ground can improve the physical properties (porosity) and soil fertility. Conditions arable land with good soil aggregation can stimulate vegetative growth of plants.

Trichoderma asperellum can multiply rapidly in the rhizosphere, and a parasitic fungus that can attack and take nutrients from other fungi (antagonist). The role of Trichoderma $s p$. antagonistic and at the same rapid breeding in the rhizosphere make the existence of this fungus can act as a biocontrol against fungi that cause diseases (Harman, 2011) for example Phytophtora palmivora causes stem rot disease, the fruit and leaves of the cocoa that can improve plant growth

\section{Conclusion}

Granting Trichoderma asperellum on cocoa seedlings planted under old cocoa trees and is still productive, able to help overcome competition in the utilization of nutrients and water as well as other growth inhibiting factors, and the influential on the vegetative growth of cocoa seedlings.

Frequency of Trichoderma sp. the best is three times the application that provides the most effective results for growing cacao seeds, the seed growing percentage of $100 \%$ and an average plant height of $144.45 \mathrm{~cm}$; number of leaves 37 strands; stem diameter $12.22 \mathrm{~mm}$; and total leaf area $1388.30 \mathrm{~cm}^{2}$.

\section{Acknowledgments}

We would like to thanks the General Directorate of Science-Tecnology Resources and Higher Education in the Ministry of Research, Technology and Higher Education.

\section{References}

Adebola, M.O., \& Amadi, J.E. (2012). Studies on Penicillium digitatum, Botryodiploidia theobromae, Alternaria tenuis and Trichoderma harzianum for Bicontrol of Phytophthora palmivora. Cocoa Black Pod Disease $\begin{array}{llll}\text { Pathogen. American-Eurasian Journal of } & \text { Agronomy, }\end{array}$ 30-34.http://dx.doi.org/10.5829/idosi.aeja.2012.5.2.2046

Adedeji, A. R., Odebode, A. C.,\& Agbeniyi, S. O. (2008). Bioassay of Five Trichoderma Strains Againts Phytophtora megakarya (Cacao Pod-rot) in Nigeria. Scientific Research and Essay, 3(9), 390-394. Retrieved from http://www.academicjournals.org/SRE

Anaeani, F., \& Frimpong, O.K. (2013). An Analysis of Yield Gap and Some Factors of Cocoa (Theobroma cacao) Yields in Ghana. SustainableAgriculture Research,2(4), 117-128. http://dx.doi.org/10.5539/sar.v2n4p117

Anonymous(2014). Badan Koordinasi Penanaman Modal, Potensi Kakao di Sulawesi Barat (Diakses tanggal 3 Juni 2014, Indonesian). Retrieved from http://regionaliinvestment.bkpm.go.id/newsipid/id/index.php

Azis, A.I., Rosmana, A., \& Vien, S.D. (2013). Pengendalian Penyakit Hawar Daun Phytophthora pada Bibit 
Kakao dengan Trichoderma asperellum. Jurnal Fitopatologi Indonesia, 9(1),15-20.Indonesian.http://dx.doi.org/10.14692/jfi.10.5.139

Bae, H., Robert, D.P., Lim, H. S., Strem, M.D., Park, S. C., Ryu, C. M., ... Bailey, B.A. (2011). Endophytic Trichoderma Isolates from Tropical Environments Delay Disease Onset and Induce Resistance Against Phytophthora capsici in Hot Pepper Using Multiple Mechanisms. Molecular Plant-Microbe Interactions, 24(3), 336-351. http://dx.doi.org/10.1094/MPMI-09-10-0221

Fosket, D.E. (1999). Plant Growth and Development: A Molecular Approach.Academic Press, San Diego, New York, London.

Harman, G.E. (2011). Trichoderma -Not Just For BiocontrolAnymore. Phytoparasitica, 39,103-108.

Hermosa, R., Viterbo, A., Chet, I., \& Monte, E. (2012). Plant-Beneficial Effects of Trichoderma and of Its Genes. Microbiology, 158, 17-25. http://dx.doi.org/10.1099/mic.0.052274-0

Hopkins, W.G. (1999).Introduction to Plant Physiology.John Wiley and Sons, Inc., New York, Brisbane, Toronto.

Nasaruddin (2011). Bahan Ajar Mata kuliah Analisis Pertumbuhan Tanaman. Universitas Hasanuddin, Makassar, Indonesian.

Nurahmi, E., Susanna,\& Sriwati, R. (2012). Pengaruh Trichoderma terhadap Perkecambahan dan Pertumbuhan Bibit Kakao, Tomat, dan Kedelai. J. Floratek, 7, 57-65. Indonesian.

Okoth, S.A., Otadoh, J.A., \& Ochanda, J.O. (2011). Improved Seedling Emergence and Growth of Maize and Beans by Trichoderma harziunum. Tropical and Subtropical Agroecosystem, 13, 65-71. Retrieved from http:/hdl.handle.net/10568/43096

Ololade, I. A., Ajayi, I. R., Gbadamosi, A. E., Mohammed, O. Z., \& Minggu, A. G. (2010). A Study on Effects of Soil Physico-Chemical Properties on Cocoa Production in Ondo State. Modern Applied Science, 4(5), 35-43. http://dx.doi.org/10.5539/mas.v4n5p35

Saba, H., Vibhash, D., Manisha, M., Prashant, K. S., Farhan, H., \& Tauseef, A. (2012).Trichoderma a Promising Plant Growth Stimulator and Biocontrol Agent. Mycosphere, 3(4), 524-531.

Worldatlas (2015). Top 10 Cocoa Producing Countries(Published: April 22, 2015; Updated: July 14, 2016). Retrieved from http://www.worldatlas.com/articles/top-10-cocoa-producing-countries.html.

\section{Copyrights}

Copyright for this article is retained by the author(s), with first publication rights granted to the journal.

This is an open-access article distributed under the terms and conditions of the Creative Commons Attribution license (http://creativecommons.org/licenses/by/4.0/). 